\title{
Exploitation of Astrocytes by Glioma Cells to Facilitate Invasiveness: A Mechanism Involving Matrix Metalloproteinase-2 and the Urokinase-Type Plasminogen Activator-Plasmin Cascade
}

\author{
Duc M. Le, ${ }^{1}$ Arnaud Besson, ${ }^{1}$ Darrin K. Fogg, ${ }^{2}$ Kyu-Sil Choi, ${ }^{2}$ David M. Waisman, ${ }^{2}$ Cynthia G. Goodyer, ${ }^{5}$ \\ Barry Rewcastle, ${ }^{3}$ and V. Wee Yong ${ }^{1,4}$ \\ Departments of ${ }^{1}$ Oncology, ${ }^{2}$ Medical Science, ${ }^{3}$ Pathology, and ${ }^{4}$ Clinical Neurosciences, University of Calgary, Calgary, Alberta, Canada, and ${ }^{5}$ McGill \\ University, Montreal Children's Hospital Research Institute, Montreal, Quebec, Canada
}

\begin{abstract}
The presence of reactive astrocytes around glioma cells in the CNS suggests the possibility that these two cell types could be interacting. We addressed whether glioma cells use the astrocyte environment to modulate matrix metalloproteinase-2 (MMP-2), a proteolytic enzyme implicated in the invasiveness of glioma cells. We found that astrocytes in culture produce significant amounts of the pro-form of MMP-2 but undetectable levels of active MMP-2. However, after coculture with the U251N glioma line, astrocyte pro-MMP-2 was converted to the active form. The mechanism of pro-MMP-2 activation in glioma-astrocyte coculture was investigated and was found to involve the urokinase-type plasminogen activator (uPA)-plasmin cascade whereby uPA bound to uPA receptor (uPAR), leading to the conversion of plasminogen to plasmin. The latter cleaved pro-MMP-2 to generate its active form. Furthermore, key components (i.e., uPAR, uPA, and pro-MMP-2) were contributed principally by astrocytes, whereas the U251N glioma cells provided plasminogen. In correspondence with this biochemical cascade, the transmigration of U251N cells through Boyden invasion chambers coated with an extracellular matrix barrier was increased significantly in the presence of astrocytes, and this was inhibited by agents that disrupted the uPA-plasmin cascade. Finally, using resected human glioblastoma specimens, we found that tumor cells, but not astrocytes, expressed plasminogen in situ. We conclude that glioma cells exploit their astrocyte environment to activate MMP-2 and that this leads to the increased invasiveness of glioma cells.
\end{abstract}

Key words: astrocytes; brain tumors; glioma; metalloproteinases; metastasis; plasmin

\section{Introduction}

Gliomas are brain neoplasms that account for $>50 \%$ of tumors that arise within the CNS. The more malignant forms, comprising anaplastic astrocytomas and the high-grade glioblastoma multiforme (GBM), may invade diffusely throughout the CNS to form foci of new growth, rendering surgery, radiation, and chemotherapies inadequate as treatment modalities. Understanding the mechanisms that regulate glioma invasiveness is critical to improve the prognosis of patients with incurable gliomas.

The family of matrix metalloproteinases (MMPs) is implicated in tumor invasion and metastasis (Sternlicht and Werb, 2001). In addition, other features of tumor evolution, including survival, growth, and angiogenesis, also may be dependent on MMPs (Chambers and Matrisian, 1997). MMP members are classified into subgroups on the basis of structure and substrate preference (Yong et al., 2001). One category, the gelatinases (MMP-2 and MMP-9), has been associated intimately with tu-

Received April 15, 2002; revised Feb. 12, 2003; accepted Feb. 19, 2003.

D.M.L. was supported by studentship awards from the National Science and Engineering Research Council of Canada and the Alberta Heritage Foundation for Medical Research. We thank the Canadian Institutes for Health Research for support of operating funds.

Correspondence should be addressed to Dr. V. Wee Yong, Departments of Oncology and Clinical Neurosciences, University of Calgary, 3330 Hospital Drive, Calgary, Alberta T2N 4N1, Canada. E-mail: vyong@ucalgary.ca. Copyright $\odot 2003$ Society for Neuroscience $\quad 0270-6474 / 03 / 234034-10 \$ 15.00 / 0$ mor invasiveness and metastasis because of its potent ability to degrade the type IV collagen present in basement membrane that surrounds blood vessels. Elevated levels of gelatinases are found in many types of human cancers (Stetler-Stevenson et al., 1993).

With respect to gliomas, the upregulation of MMP-2 and MMP-9 has been observed in cell lines and resected specimens (Rutka et al., 1995; Saxena et al., 1995; Sawaya et al., 1996; Forsyth et al., 1998, 1999; Lampert et al., 1998; Beliveau et al., 1999; Pagenstecher et al., 2001; VanMeter et al., 2001; Wild-Bode et al., 2001). In vivo the expression of MMP-2, determined by in situ hybridization or immunohistochemistry, is principally in glioma cells, whereas MMP-9 expression tends to be predominant in regions of angiogenesis (for review, see Forsyth et al., 2001). These analyses implicate MMP-2 in the growth or invasiveness of gliomas in situ, whereas MMP-9 may be associated with angiogenesis. In support, there is a high correlation between the capacity of cultured glioma cell lines to invade across an artificial basement membrane, Matrigel, and their expression of MMP-2 (Uhm et al., 1996). Inhibitors of metalloproteinases reduce the invasiveness of glioma cell lines in vitro (Uhm et al., 1996; Tonn et al., 1999) and attenuate the growth of glioma cells implanted into the flank of severe combined immunodeficient (SCID) mice (Price et al., 1999).

MMPs are produced by cells as pro-enzymes, and they require 
further processing to generate the active enzyme. The activation of pro-MMPs is facilitated by active forms of other MMPs or by other groups of proteinases (Nagase, 1997). For example, a serine proteinase, plasmin, can activate gelatinases without the need for any intermediaries (Mazzieri et al., 1997).

The mechanism by which gliomas modulate their MMP-2 content or activity remains unclear. Because glioma cells produce factors that promote the proliferation (Couldwell et al., 1992) and motility (Lal et al., 1996) of astrocytes, we have tested the hypothesis that glioma cells exploit their astrocyte environment for MMP-2 production and activation and that the consequence of this interaction is the increased ability of glioma cells to invade. We also have addressed the mechanisms of the glioma exploitation of astrocytes for invasion.

\section{Materials and Methods}

Detection of reactive astrocytes in proximity to glioma cells in situ. Specimens obtained from surgical resections of human brain tumors were immersion-fixed in $10 \%$ neutral buffered formalin and subsequently were embedded in paraffin. Tissue sections were cut $(5 \mu \mathrm{m})$ and processed for immunoreactivity for glial fibrillary acidic protein (GFAP), an astrocyte-specific marker. In brief, first the sections were deparaffinized (xylene, $3 \times$; $95 \%$ ethanol, $3 \times$ ) for $20 \mathrm{~min}$. Blocking of endogenous peroxidase activity was achieved by incubating sections in $1 \% \mathrm{H}_{2} \mathrm{O}_{2}$ in methanol for $15 \mathrm{~min}$. Antigen recovery ensued by incubating sections in $0.05 \%$ trypsin and $2 \% \mathrm{CaCl}_{2}, \mathrm{pH} 7.5$, at $37^{\circ} \mathrm{C}$ for $20 \mathrm{~min}$. After being blocked with nonimmune serum, the sections were incubated with the primary antibody (rabbit anti-GFAP, Dako, Mississauga, Ontario) for 3 hr in a humidity chamber at room temperature. After the sections were rinsed, a secondary antibody was applied. Sections were treated with avidin-biotin-peroxidase $(\mathrm{ABC})$ complex (Vector Laboratories, Burlington, Ontario), and immunoreactivity was visualized by using diaminobenzidine $(\mathrm{DAB})$ as the chromogen. Sections were counterstained with hematoxylin and examined with a light microscope.

To implant human glioma cells into the brain of mice, we anesthetized SCID NOD mice with ketamine (200 mg/kg, i.p.) and xylazine $(10 \mathrm{mg} /$ $\mathrm{kg}$, i.p.) and secured them in a stereotactic apparatus. After a midline incision exposed the skull, a $0.9 \mathrm{~mm}$ burr hole was made $1 \mathrm{~mm}$ lateral to the midline, half-way between the lambda and bregma sutures. U87 or $\mathrm{U} 251 \mathrm{~N}$ cells $(100,000$ cells) suspended in $2 \mu$ l of saline were injected into the mouse brain with a $5 \mu$ l Hamilton syringe. The needle was removed slowly, and the skin was sutured. Mice were given $2 \mathrm{ml}$ of saline (injected subcutaneously) and were allowed to recover on a heating pad. On day 25 after surgery the mice were killed, and brains were harvested and immersion-fixed in $10 \%$ neutral buffered formalin. After fixation the brains were embedded in paraffin, and $5-\mu \mathrm{m}$-thick coronal sections were used for GFAP immunoreactivity.

To attempt colocalization of plasminogen on glioma cells or astrocytes in situ, we used a human brain tumor specimen. Specifically, a paraffinembedded specimen containing glioblastoma cells that were GFAPnegative was used to allow for their differentiation from neighboring GFAP-positive astrocytes. After deparaffinization, antigen recovery, and blocking as described above, $6 \mu \mathrm{m}$ sections were incubated with a polyclonal rabbit anti-GFAP (Dako), followed by anti-rabbit Ig Cy3 (1:500; Molecular Probes, Leiden, The Netherlands). Then a mouse monoclonal antibody to human plasminogen (number 3644, $10 \mu \mathrm{g} / \mathrm{ml}$; American Diagnostica, Greenwich, CT) and anti-mouse Ig Alexa 488 were used. Finally, the sections were incubated with Hoechst 33852 (Sigma, St. Louis, MO) for 10 min to label all cell nuclei.

Cell culture. The U251N and U87 cell lines are multiply passaged human glioblastoma cells (Ishii et al., 1999), the use for which has been noted previously (Besson and Yong, 2000); we have selected these for study because these human lines grow well in the brains of immunocompromised mice. Human fetal astrocytes were cultured from brains obtained from therapeutic abortions. The use of these specimens was approved by institutional human ethics committees. Astrocytes of $>99 \%$ purity were prepared as described in detail previously (Vecil et al., 2000).
Glioma cells or astrocytes were maintained in MEM supplemented with $10 \%$ fetal calf serum, $1 \times$ nonessential amino acids, $1 \mathrm{~mm}$ sodium pyruvate, 2 mu glutamine, and $0.5 \%$ dextrose. All culture medium constituents were obtained from Invitrogen (Burlington, Ontario). When cells were used in experiments to measure the content or activity of MMP-2, the medium was changed over to an RPMI-based serum-free but hormonally supplemented medium (M2; Boutros et al., 1997) containing $0.5 \%$ dextrose, $25 \mu \mathrm{g} / \mathrm{ml}$ insulin, $100 \mu \mathrm{g} / \mathrm{ml}$ transferrin, $20 \mathrm{~nm}$ progesterone, $50 \mu \mathrm{m}$ putrescine, and $30 \mathrm{~nm}$ sodium selenite. M2 serum-free medium was necessary because fetal calf serum contains a variety of MMPs that would obscure MMP-2 produced by cells.

In experiments to detect MMP-2, unless otherwise stated, 1 million human fetal astrocytes (HFA) or U251N glioma cells were cultured alone in six-well culture plates or were cocultured $(500,000$ cells for each cell type) for $24 \mathrm{hr}$. The volume of medium was $1.5 \mathrm{ml} /$ well. For each experiment two separate culture duplicates were used per condition (thus accounting for duplicate lanes in zymography; see Results). When inhibitors were used to test the requirement of various protease subclasses to activate MMP-2, these were added immediately after coculture of the cells. The following inhibitors were used: pepstatin A, E-64 [transepoxysuccinyl-L-leucylamido-(4-guanidino)-butane], aprotinin (from Sigma-Aldrich, Oakville, CA), $\alpha_{2}$-antiplasmin (Calbiochem, La Jolla, $\mathrm{CA})$, and recombinant human tissue inhibitors of metalloproteinases (TIMPs) - 1 or -2 (generously provided by Dr. Dylan Edwards, University of East Anglia, Norwich, UK). These inhibitors were used at concentrations described to be effective in culture (Uhm et al., 1996).

Analyses of MMP-2 level and activity. As with all MMPs, MMP-2 exists in a pro- and active form. To detect both forms simultaneously, we used a gelatin zymography protocol (Uhm et al., 1996). Because the gelatinases are secreted proteases, the amount of pro- and active MMP-2 produced by cells was examined by assaying the cell-conditioned medium after $24 \mathrm{hr}$ of exposure. The cell-conditioned medium was mixed with $4 \times$ gel-loading buffer; $80 \mu \mathrm{l}$ was electrophoresed in a 10\% SDS-gel containing $1 \mathrm{mg} / \mathrm{ml}$ gelatin. The gel was incubated overnight in rinse buffer (50 mu Tris, pH 7.5, $5 \mathrm{~mm} \mathrm{CaCl}_{2}$, and 2.5\% Triton X-100) at room temperature to wash away the SDS, thus allowing the gelatinases to renature. Then the gel was placed in a reaction buffer ( $50 \mathrm{~mm}$ Tris, $\mathrm{pH} 7.5$, and $5 \mathrm{~mm} \mathrm{CaCl}_{2}$ ) for $18 \mathrm{hr}$ to facilitate gelatin degradation by gelatinases. Next the gel was incubated for at least $4 \mathrm{hr}$ in Coomassie blue stain solution. The gel was destained by $10 \%$ isopropanol and $10 \%$ acetic acid. Areas of gelatinase activity, given the paucity of gelatin in these zones, were observed as clear bands against a dark background. The locations of pro- and active MMP-2 were based on molecular weight determinations and by confirmations with the resolved pattern of recombinant human MMP-2 (Oncogene, Cambridge, MA). Previous experiments that used MMP-2 antibodies to deplete this gelatinase from conditioned media have confirmed the locations of pro- and active MMP-2 (Uhm et al., 1996). It should be noted that, although pro-MMP-2 is an inactive zymogen in its native state, by virtue of the cysteine residue in the propeptide interacting with zinc atom at the catalytic site, the dissociation of the cysteine-zinc interaction during electrophoresis allows the pro-MMP-2 to degrade gelatin and to be identifiable as a white band in zymograms.

Although zymography is based on the ability of gelatinases to degrade gelatin, the resultant size of the band of gelatin degradation is a direct reflection of the amounts of pro- and active gelatinases rather than their intrinsic enzyme activity. Thus to measure MMP-2 enzyme activity directly, we used an MMP-2 fluorogenic substrate, MCA-Pro-Leu-AlaNva-Dpa-Ala-Arg- $\mathrm{NH}_{2}$ (Calbiochem). When cleaved by active MMP-2, the quenched fluorescence was emitted. Then $50 \mu \mathrm{l}$ of $24 \mathrm{hr}$ cellconditioned medium was added to individual wells of a 96-well culture plate. MMP-2 substrate ( $50 \mu \mathrm{l}$ of $50 \mu \mathrm{M}$ stock solution) was added to the wells. Fluorescence was monitored for $1 \mathrm{hr}$ in a PerkinElmer Life Sciences (Emeryville, CA) HTS 7000 Bioassay Reader (excitation wavelength of $325 \mathrm{~nm}$ and emission wavelength of $393 \mathrm{~nm}$ ) and expressed as relative fluorescence units.

The total level of MMP-2 (pro- and active) also was measured by using an MMP-2 ELISA (Oncogene) according to the manufacturer's instructions. Medium conditioned for $24 \mathrm{hr}$ by the cells was collected, and $50 \mu \mathrm{l}$ was added for analysis. 
Plasmin activity assay. Because plasmin activity was low in cells in six-well plates, $100 \mathrm{~mm}$ dishes were seeded with astrocytes (5 million cells/dish), U251N cells ( 5 million cells/dish) or astrocyte-U251N cocultures ( 2.5 million cells/dish of each cell type). Serum-free M2 medium (4 $\mathrm{ml} / \mathrm{dish}$ ) was used, and the cells were incubated at $37^{\circ} \mathrm{C}$ for $24 \mathrm{hr}$. Each conditioned medium was collected and cleared by centrifugation. The supernatant was concentrated centrifugally 100 -fold with Ultrafree centrifugal filter tubes (Millipore, Bedford, MA) that retained molecules $>10 \mathrm{kDa}$. Concentrated supernatant $(0.5 \mathrm{ml})$ was added to 24 -well culture plates, followed by $20 \mu \mathrm{l}(0.2 \mathrm{~mm})$ of AFC- 80 (7-amino-4trifluoromethy coumarin: Z-Ala-Lys-Lys) plasmin substrate (Enzyme Systems Products, Livermore, CA). Fluorescence was monitored for $1 \mathrm{hr}$ (excitation wavelength of $405 \mathrm{~nm}$ and emission wavelength of $535 \mathrm{~nm}$ ) and expressed as relative fluorescence units.

uPAR immunofluorescence. Astrocytes (10,000 cells) or U251N cells (10,000 cells) were seeded onto $12 \mathrm{~mm}$ glass coverslips. After adherence and morphological differentiation the cells were untreated or treated with $10 \mathrm{U} / \mathrm{ml}$ phospholipase $\mathrm{C} \gamma$ (PI-PLC; Molecular Probes, Leiden, Netherlands) for $1 \mathrm{hr}$ at $37^{\circ} \mathrm{C}$. PI-PLC was removed, and the cells were incubated at $37^{\circ} \mathrm{C}$ overnight before being fixed with $2 \%$ paraformaldehyde for $20 \mathrm{~min}$. The primary antibody (1:500 dilution of mouse antiuPAR; American Diagnostica) was added to the coverslip and incubated at room temperature for $1 \mathrm{hr}$. Coverslips were rinsed three times with PBS. Secondary antibody (1:500 dilution of goat anti-mouse Alexa 488) was applied for $1 \mathrm{hr}$ at room temperature. Cells then were permeabilized with $0.2 \%$ Triton X-100 for 3 min. Phalloidin (1:1000 dilution; Molecular Probes), staining filamentous actin to highlight cell boundaries, was applied for $1 \mathrm{hr}$ at room temperature. After being rinsed with PBS, the coverslips were mounted onto glass slides. Sections were viewed with an Olympus confocal laser-scanning microscope, and images were acquired with the Olympus Fluoview program (version 3.0).

Western blotting experiments. The $100 \mathrm{~mm}$ dishes were seeded with astrocytes ( 5 million cells), U251N cells (5 million cells), or astrocyteU251N cells ( 2.5 million cells of each cell type) in M2 medium and incubated at $37^{\circ} \mathrm{C}$ for $24 \mathrm{hr}$. Samples were performed in duplicate. Conditioned medium was collected, cleared by centrifugation, and concentrated 100-fold as described earlier. To obtain cell lysates, we rinsed culture dishes three times with PBS. Cells then were exposed to $200 \mu \mathrm{l}$ lysis buffer [containing (in mM): 50 HEPES, pH 7.5, 50 NaCl, 1 EDTA, 2.5 EGTA plus $0.1 \%$ Tween-20, $1 \%$ Nonidet P-40, $0.2 \%$ SDS, $10 \%$ glycerol complemented with (in mM) 1 DTT, $10 \beta$-glycerophosphate, 1 NaF, 0.1 sodium orthovanadate, $1 \mathrm{PMSF}$, and (in $\mu \mathrm{g} / \mathrm{ml}$ ) 10 leupeptin, 10 aprotinin, 10 pepstatin A]. A 26 gauge needle was used to homogenize the lysate, which then was left on ice for $10 \mathrm{~min}$. The lysate was centrifuged $(10,000 \mathrm{rpm})$ for $10 \mathrm{~min}$, and the supernatant was kept. The total protein content per sample was analyzed by Bradford protein assay (Bio-Rad, Hercules, CA). Protein loading buffer $(4 \times, 200 \mathrm{~mm}$ Tris-HCl, pH 7.8, $400 \mathrm{~mm}$ DTT, $8 \%$ SDS, $0.4 \%$ bromophenol blue, and $40 \%$ glycerol) was added to each sample. Equal amounts $(150 \mu \mathrm{g})$ of protein from cell lysates or equal volumes of conditioned media were subjected to $8 \%$ SDS-PAGE. Then the proteins were transferred onto a polyvinylidene difluoride (PDVF) membrane (Millipore). Membranes were blocked in a blocking solution (PBS containing 0.5\% Tween-20 and 5\% powered milk) and incubated with primary antibodies (1:500 dilution of antiuPAR) overnight at $4^{\circ} \mathrm{C}$. Finally, the membranes were rinsed with PBS containing $0.1 \%$ Tween-20 and incubated in secondary antibody (1:10,000 dilution) for $1 \mathrm{hr}$ at room temperature. ECL (Amersham Biosciences, Uppsala, Sweden) was used for detection.

Invasion assays. In vitro invasion assays were performed in $8 \mu \mathrm{m}$ pore size Matrigel-coated invasion chambers (Becton Dickinson, Bedford, MA) as described previously (Uhm et al., 1996). Astrocytes (5000 cells) were seeded onto the top compartment of each chamber (placed in 24well culture plates) and incubated at $37^{\circ} \mathrm{C}$ for $4 \mathrm{hr}$. Then U251N cells $(25,000$ cells) suspended in M2 were plated onto the astrocytes. Because astrocytes also may invade across the Matrigel barrier, the U251N glioma cells were stably transfected with a LacZ construct so that glioma cells could be differentiated from astrocytes on the basis of galactosidase activity. After G418 selection and histochemical staining (see below), all glioma cells were $\beta$-galactosidase-positive (data not shown).
Medium conditioned by NIH3T3 fibroblasts was placed in the bottom well of the invasion chambers to act as a directional chemoattractant force for glioma invasion. The entire chamber setup, in triplicate for each experimental condition, was incubated for $68 \mathrm{hr}$ at $37^{\circ} \mathrm{C}$. Then the cells were fixed with $0.4 \%$ paraformaldehyde for $15 \mathrm{~min}$. $\beta$-Galactosidase staining was performed by first rinsing the invasion chambers with phosphate buffer ( $77 \mathrm{mM} \mathrm{Na}_{2} \mathrm{HPO}_{4} ; 23 \mathrm{mM} \mathrm{NaH}_{2} \mathrm{PO}_{4}$, adjusted to $\mathrm{pH} 7.4$ ) for $1 \mathrm{~min}$, followed by fixation with the $\beta$-gal fixation buffer $(0.25 \%$ glutaraldehyde, $0.1 \mathrm{M} \mathrm{Na}_{2} \mathrm{HPO}_{4}, 0.1 \mathrm{M} \mathrm{NaH} \mathrm{H}_{2} \mathrm{PO}, 2 \mathrm{mM} \mathrm{MgCl}_{2}$, and $125 \mathrm{~mm}$ EGTA) for $15 \mathrm{~min}$. After being washed three times with a wash buffer $(0.1$ $\mathrm{M} \mathrm{Na}_{2} \mathrm{HPO}_{4 ;} 0.1 \mathrm{M} \mathrm{NaH} \mathrm{PO}_{4}, 2 \mathrm{~mm} \mathrm{MgCl}, 0.01 \%$ desoxycholic acid, and $0.02 \%$ IGEPAL; 15 min each time), the chambers were left overnight in the $\beta$-gal staining buffer [containing $0.1 \mathrm{M} \mathrm{Na}_{2} \mathrm{HPO}_{4}, 0.1 \mathrm{M} \mathrm{NaH} \mathrm{NO}_{4}$, and (in mM) $2 \mathrm{MgCl}_{2}, 5 \mathrm{~K}_{4} \mathrm{Fe}(\mathrm{CN})_{6}-3 \mathrm{H}_{2} \mathrm{O}, 5 \mathrm{~K}_{3} \mathrm{Fe}(\mathrm{CN})_{6}, 1$ spermidine plus $0.01 \%$ desoxycholic acid and $1 \mathrm{mg} / \mathrm{ml} \mathrm{X}$-gal] at $37^{\circ} \mathrm{C}$. Cells were refixed, in $95 \%$ ethanol, for $20 \mathrm{~min}$. A cotton-tipped swab was applied to the top surface of the membrane to remove cells that did not transmigrate across the invasion chamber. Each membrane then was cut out and mounted onto glass slides. Cells that stained blue (i.e., glioma) were counted with a light microscope.

MTT cell viability assays. Viability of cells was determined with the 3-(4,5-dimethylthiazol-2-yl)-2,5-diphenyltetrazolium bromide thiazolyl blue (MTT) assay. Astrocytes (10,000 cells) or U251N cells (10,000 cells) were seeded in wells of a 96-well culture plate. These were incubated, in triplicate, with test factors at $37^{\circ} \mathrm{C}$ for $24 \mathrm{hr}$. MTT $(20 \mu \mathrm{l} ; 0.5$ $\mathrm{mg} / \mathrm{ml}$ ) was added per well for an additional $1 \mathrm{hr}$ at $37^{\circ} \mathrm{C}$. Wells were rinsed twice with PBS; $100 \%$ DMSO $(200 \mu \mathrm{l})$ was applied to each well to solubilize the MTT color. Absorbance of each sample was measured by a spectrophotometer at a wavelength of $550 \mathrm{~nm}$ and expressed as relative absorbance units.

\section{Results \\ Astrocytes become reactive in the vicinity of glioma cells in situ}

When the CNS is subjected to a variety of insults, astrocytes undergo typical reactive changes in a phenomenon called astrogliosis (Yong, 1998). Similarly, in the proximity of tumor cells in sections from patients with glioma, reactive astrocytes were detected by increased GFAP immunoreactivity (Fig. 1). Reactive astrocytes abutted glioma cells that had infiltrated some distance from the primary tumor mass (Fig. $1 A$, from a patient with malignant astrocytoma) and also were found within a tumor mass of another type of glioma, oligodendroglioma (Fig. $1 B$ ).

To confirm the occurrence of reactive astrocytes in the presence of neoplastic growth, we implanted U87 or U251N glioma cells into the brains of SCID mice. These cell lines were chosen for their capacity to readily grow intracerebrally. At $25 \mathrm{~d}$ after implantation a significant mass of tumor cells was observed (Fig. 1C). Astrocytes at the interface of glioma and brain parenchyma had an increase in GFAP immunoreactivity, indicating their reactivity.

\section{Activation of pro-MMP-2 occurs in glioma-astrocyte coculture}

The observation that astrocytes become reactive when encountering glioma cells in situ suggests the possibility that the two cell types could be interacting. Specifically, we used tissue culture paradigms to examine whether glioma cells exploit astrocytes to facilitate their invasion. The levels of pro- and active MMP-2 secreted by astrocytes and U251N cells were examined first in their 24 hr conditioned media by gelatin zymography. Astrocyteconditioned medium contained a high level of pro-MMP-2 but negligible amounts of active MMP-2. The medium collected from $\mathrm{U} 251 \mathrm{~N}$ cells contained low but detectable levels of both proand active MMP-2 (Fig. $2 \mathrm{~A}$ ). Interestingly, when astrocytes were 

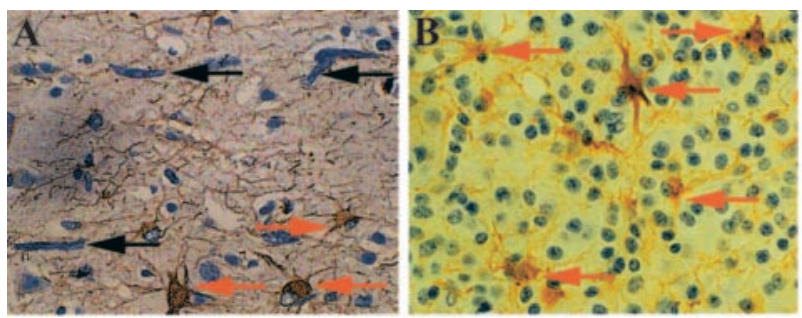

C
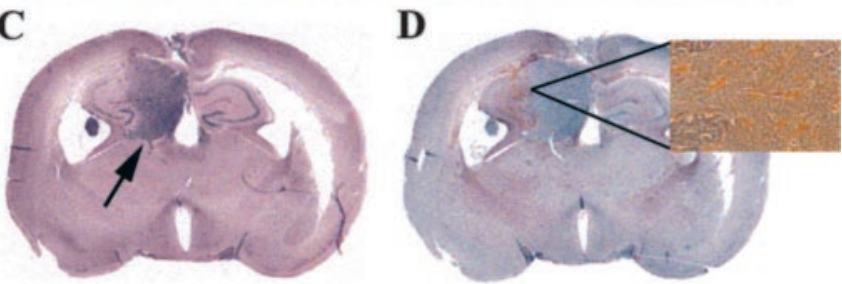

Figure 1. Reactive astrocytes are found in proximity to glioma cells in situ. Immunoreactivity for GFAP (brown cells) reveals reactive astrocytes in the proximity of glioma cells; samples are counterstained with hematoxylin. $A$, This section from a patient with malignant astrocytoma shows elongated glioma cells (black arrows) that have infiltrated into the cortex (at least $3 \mathrm{~cm}$ away) from the main tumor mass in a subcortical region. Reactive astrocytes are depicted with red arrows. $B$, Astrocytes (red arrows) are seen reacting to oligodendroglioma cells within the mass of the tumor. C, Significant tumor growth (indicated by the black arrow) in the hippocampus is observed in the brains of SCID mice $25 \mathrm{~d}$ after implantation of $U 87$ glioma cells, as revealed with hematoxylin and eosin staining. An adjacent section in D shows increased levels of GFAP immunoreactivity (brown speckles in the coronal section) in the tumor-brain interface. The inset in $D$ is a high-power view of the indicated area to better display the reactive astrocytes. Similar results were observed for implanted U251N cells (data not shown).

cocultured with U251N cells, high levels of active MMP-2 were generated (Fig. 2A).

We corroborated the activation of MMP-2 in cocultures by using an MMP-2 substrate-specific degradation assay. Astrocyteconditioned medium showed no detectable MMP-2 activity, whereas moderate levels were detected in the U251N-conditioned medium. Significantly, conditioned medium from the astrocyteU251N coculture displayed the highest level of MMP-2 activity (Fig. $2 B$ ), thus mirroring the results of zymography.

Given the astrogliosis in mouse brain implanted with human tumors (Fig. 1D), mouse astrocytes were assessed to determine whether they behaved similarly to their human counterparts in vitro. It was found that mouse astrocytes produced pro- but little active MMP-2, similar to human cells. Furthermore, when mouse astrocytes were cocultured with U251N glioma, high levels of active MMP-2 were detected (data not shown). These results demonstrate that the mechanisms that generate active MMP-2 in glioma-astrocyte interactions do not depend on species-specific factors.

Activation of MMP-2 in glioma-astrocyte interaction requires live astrocytes and glioma-soluble factors

To elucidate the mechanism of MMP-2 activation in the U251Nastrocyte cocultures, we first determined whether the presence of cells was required. Conditioned media were collected from astrocytes or U251N cells, mixed in equal parts, and incubated for 24 hr. Gelatin zymography of the resulting medium did not reveal any increase of active MMP-2, suggesting that the presence of cells (astrocyte and/or U251N cells) was necessary for the conversion of proMMP-2.

To test which live cell type was essential for the activation of the MMP-2 zymogen, we cultured astrocytes in U251Nconditioned medium for $24 \mathrm{hr}$. Gelatin zymography detected levels of active MMP-2 similar to those seen in glioma-astrocyte

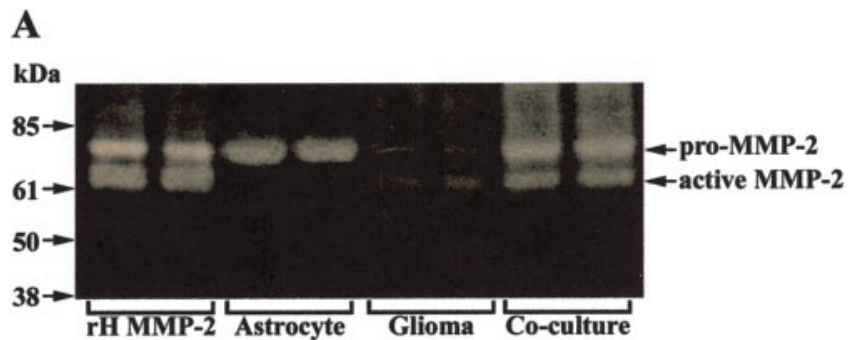

B
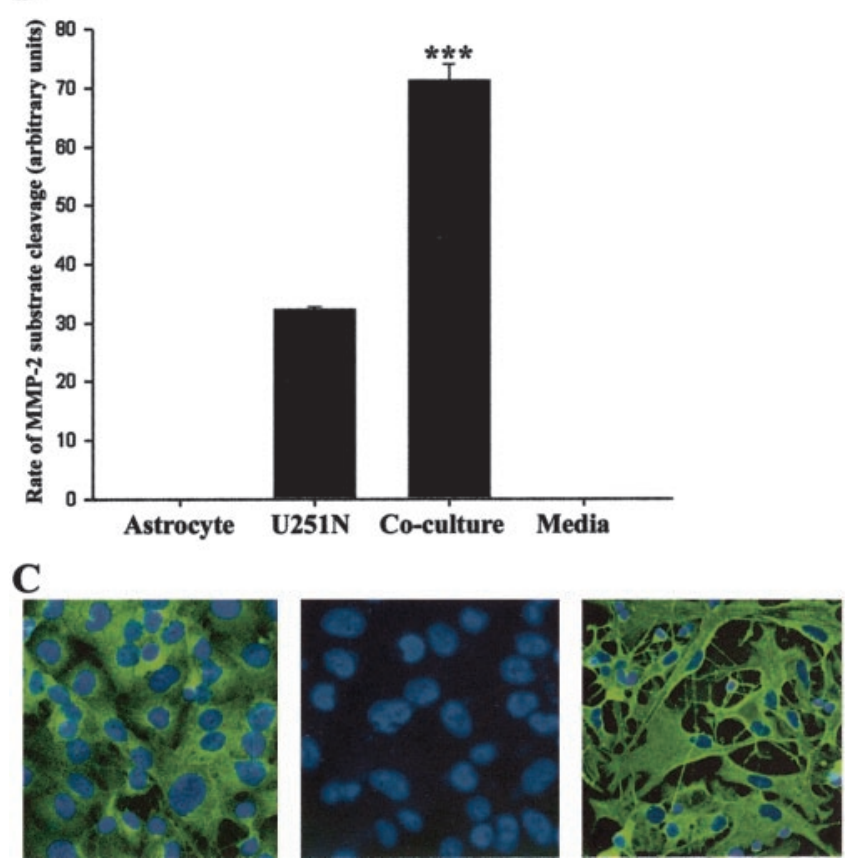

Figure 2. Activation of pro-MMP-2 in cocultures of astrocytes and U251N glioma cells. A Gelatin zymogram of pro- and active MMP-2 is displayed. Recombinant human (rH) MMP-2 was used as a standard for both pro- and active MMP-2, which were $\sim 72$ and $65 \mathrm{kDa}$, respectively. Although the conditioned medium of astrocytes contained high levels of pro-MMP-2 and negligible active MMP-2, U251N glioma cells secreted very low but detectable levels of both forms. In the coculture of astrocytes with U251N cells, pro-MMP-2 remained high; significantly, a substantial amount of active MMP-2 was generated. This result has been replicated in $>20$ experiments in which each test condition was always performed in duplicate (duplicate lanes per condition are displayed for this and other zymograms). $B$, The amount of active MMP-2 present in the conditioned medium of cells is documented by degradation of fluorescent substrate. In correspondence with the zymography data, increased MMP-2 activity was generated in U251N glioma-astrocyte coculture. The media histogram refers to feeding medium that had not been exposed to cells. Values shown are the mean \pm SEM of triplicate samples from a single experiment. This result has been reproduced in two other experiments; ${ }^{* * *} p<0.001 \mathrm{com}$ pared against U251N glioma, one-way ANOVA with Bonferroni post hoc test. C, Shown is the GFAP status of cells, whereby the U251N cells (left panel) were found to contain GFAP intermediate filament protein (green stain) as do the fetal astrocytes (right panel); in the middle panel the primary anti-GFAP antibody has been omitted from the staining of U251N cells. All cells were counterlabeled with Hoechst dye to illuminate their nuclei. The presence of GFAP immunoreactivity in the U251 line used here indicates that the results of this manuscript are not attributable to the loss of GFAP expression, which can confer to glioma cells a more invasive phenotype (Rutka and Smith, 1993).

cocultures (Fig. 3A), indicating that the presence of glioma cells could be substituted by their soluble factors. Conversely, when $\mathrm{U} 251 \mathrm{~N}$ cells were cultured in astrocyte-conditioned medium for $24 \mathrm{hr}$, no active MMP-2 was generated (Fig. 3B). Thus live astrocytes were required for proMMP-2 to be activated in cocultures.

In summary, a minimal requirement for MMP-2 activation is the presence of live astrocytes and the conditioned medium of glioma cells. 
A

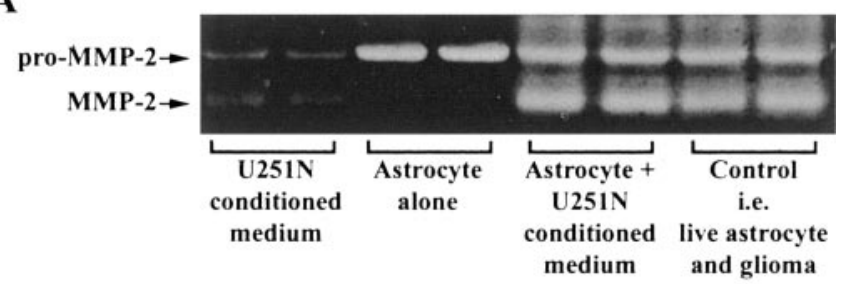

B

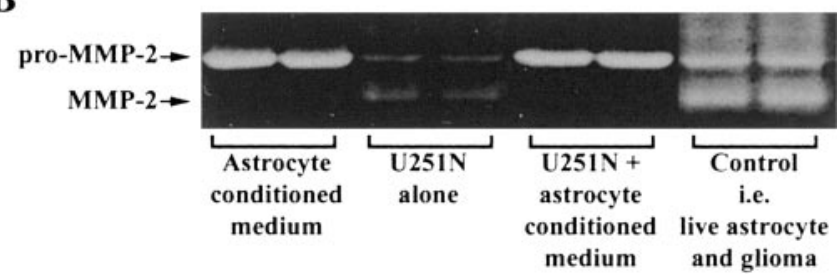

Figure 3. Pro-MMP-2 activation occurs in the presence of live astrocytes and glioma-soluble factors. The coculturing of live astrocytes and live U251N cells (Control) resulted in high levels of active MMP-2 (last 2 lanes of $A, B$ ). However, activation of MMP-2 required the presence of live astrocytes if glioma-conditioned medium were present $(A)$. Activation of MMP-2 did not occur when live glioma cells were incubated with astrocyte-conditioned medium $(B)$. This result was replicated in three separate experiments. For comparison, duplicate lanes of conditioned media from U251N or astrocytes or of cells alone are displayed also.

Other MMPs do not appear to be important in the pro-MMP2 activation that results from glioma-astrocyte engagement The requirement for live astrocytes to facilitate the activation of proMMP-2 in the U251N-astrocyte coculture suggests the possible involvement of the transmembrane forms of MMPs (the MT-MMPs), which have been implicated in the activation of pro-MMP-2 (Pei and Weiss, 1996). Because TIMPs at high concentrations inhibit MMP activity, including that of MT-MMPs, we tested whether MMP-2 activation could be blocked in glioma-astrocyte coculture by TIMP-1 or TIMP-2. The results demonstrate that the activation of pro-MMP-2 still occurred in the coculture in the presence of TIMPs (Fig. 4A). Thus other MMPs, including MT-MMPs, did not play a key role in the activation of pro-MMP-2 in glioma-astrocyte engagement.

\section{Plasmin mediates pro-MMP-2 activation in}

glioma-astrocyte interaction

We investigated whether non-MMP proteases were involved in the activation of pro-MMP-2. Inhibitors of specific protease families were applied to glioma-astrocyte cocultures, and the conditioned media after $24 \mathrm{hr}$ were collected and examined by gelatin zymography. Figure $4 B$ demonstrates that E- 64 and pepstatin A, which are inhibitors of the cysteine or aspartic proteinase families, respectively, did not attenuate the level of active MMP-2 resulting from glioma-astrocyte coculture when compared with controls without the inhibitors added. On the other hand, aprotinin decreased MMP-2 activation, implicating serine proteases in the activation of MMP-2.

A serine proteinase, plasmin, has been described as an activator of many MMPs (Mazzieri et al., 1997; Andreasen et al., 2000). A physiological and specific inhibitor of plasmin, $\alpha_{2}$-antiplasmin, was used to address whether plasmin was responsible for the activation of MMP-2 in glioma-astrocyte interaction. $\alpha_{2}-$ Antiplasmin reduced MMP-2 activation (Fig. 4B,C), implicating plasmin as key to the conversion of MMP-2 zymogen to its active form in glioma-astrocyte interaction.

We considered that the decreased activation of MMP- 2 in the presence of aprotinin or $\alpha_{2}$-antiplasmin might be the result of a

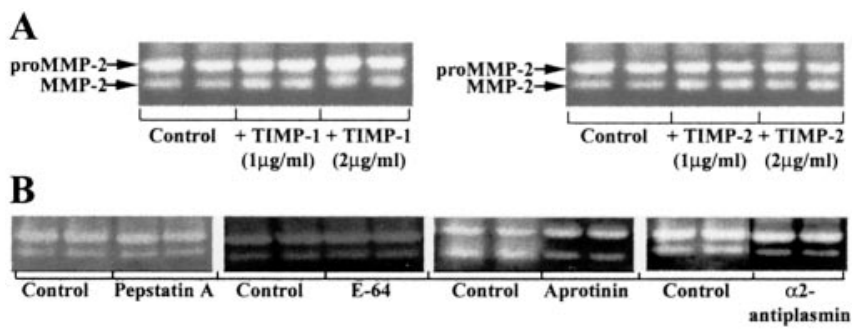

C

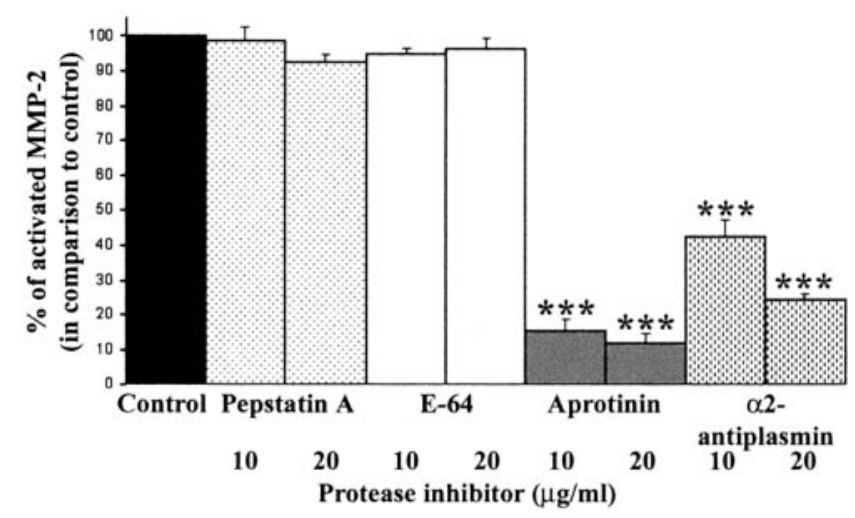

Figure 4. The use of protease inhibitors implicates plasmin in the activation of pro-MMP-2 in glioma-astrocyte cocultures. $A$, The addition of TIMP-1 and -2 did not affect the activation of MMP-2 in glioma-astrocyte cocultures, thereby excluding the participation of MMPs. A mixture of TIMP-1 $(2 \mu \mathrm{g} / \mathrm{ml})$ and TIMP-2 $(2 \mu \mathrm{g} / \mathrm{ml})$ was also ineffective at preventing pro-MMP-2 activation (data not shown). $B$, Shown are representative gelatin zymograms of conditioned media collected after $24 \mathrm{hr}$ for U251N-astrocyte cocultures with ( $20 \mu \mathrm{g} / \mathrm{ml}$ ) or without (Control) protease inhibitors; each condition was assessed in duplicate. Pepstatin A and E-64 did not block pro-MMP-2 activation, whereas aprotinin, an inhibitor of serine proteinases, and $\alpha_{2}$ antiplasmin (an inhibitor of the serine proteinase plasmin) attenuated active MMP-2 levels. These results were replicated in five experiments. C, The level of active MMP-2 generated in five cocultures of U251N-astrocyte was normalized to control cultures; then the level of active MMP-2 in treated cultures was expressed as a percentage of this normalized control. Values are the mean \pm SEM; ${ }^{* * *} p<0.001$ compared with control, one-way ANOVA with Bonferroni post hoc comparisons. Thus the activation of MMP- 2 is attenuated by aprotinin and $\alpha 2$-antiplasmin, implicating plasmin as an intermediary in the activation of MMP-2 in glioma-astrocyte cocultures.

decrease in either MMP translation or cytotoxicity instead of an inhibition of pro-MMP-2 activation. To address this, we determined total MMP-2 levels in U251N-astrocyte cocultures, with or without aprotinin $(20 \mu \mathrm{g} / \mathrm{ml})$ or $\alpha_{2}$-antiplasmin $(20 \mu \mathrm{g} / \mathrm{ml})$, by using a total MMP-2 ELISA (which picks up both pro- and active forms). The results show that total MMP-2 levels were similar for all three conditions (ELISA arbitrary units of total MMP-2 for control coculture, $0.22 \pm 0.01$; for coculture plus aprotinin, $0.23 \pm 0.01$; for coculture plus $\alpha_{2}$-antiplasmin, $0.30 \pm$ 0.01 ; mean \pm SEM).

Because the use of inhibitors implicated plasmin in the activation of MMP-2, a necessary step was to confirm the presence of plasmin in cultures containing both astrocytes and U251N cells. By virtue of a plasmin substrate degradation assay, it was found that, although the U251N and astrocyte cultures by themselves did not contain appreciable plasmin activity, this activity was elevated significantly in the coculture of glioma with astrocytes (Fig. 5).

In summary, the results reveal that plasmin is generated in glioma-astrocyte cocultures and that this leads to the activation of pro-MMP-2 produced by astrocytes. 


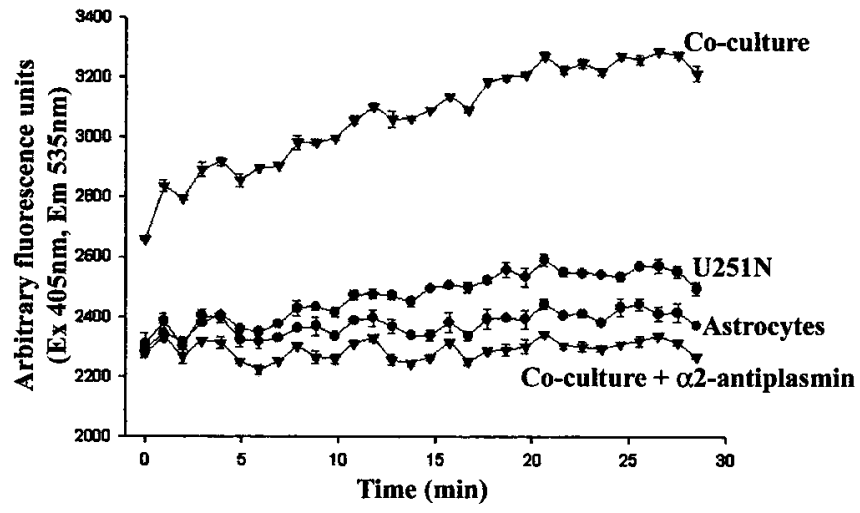

Figure 5. Plasmin activity is high in U251N-astrocyte cocultures. Plasmin activity was assessed with a fluorochrome-conjugated plasmin substrate, AFC-80, and the increase in fluorescence over time was monitored. Conditioned media of astrocytes or U251N cells in isolation had low levels of plasmin activity, but, when the cells were cocultured, high plasmin activity was obtained. That the enzymatic activity was attributable to plasmin was shown by the inhibition of activity in cocultures to which $\alpha_{2}$-antiplasmin $(10 \mu \mathrm{g} / \mathrm{ml}$ ) was supplemented. This experiment was replicated three times with similar results. Note that the fluorescent intensity graph for the coculture starts from a higher point than for the other conditions that were examined because the degradation of the fluorogenic substrate occurs instantaneously in the cocultureconditioned medium, and we could not catch the initial plasmin level in time.

\section{Contribution of components of the uPA-plasmin cascade by} glioma and astrocytes

A well described proteinase cascade involves urokinase-type plasminogen activator ( $\mathrm{uPA}$ ) that converts the zymogen, plasminogen, to active plasmin (Andreasen et al., 2000). Furthermore, active $\mathrm{uPA}$ is formed from pro-uPA binding to a receptor on cells, uPAR (urokinase plasminogen activator receptor). Thus we evaluated the relative contribution by glioma and astrocytes of these components of the uPA-plasmin cascade.

The level of plasminogen was detected in conditioned medium by using the plasmin substrate AFC- 80 in the presence of uPA. If plasminogen were present in the conditioned medium, then the addition of uPA would convert plasminogen to plasmin, resulting in degradation of AFC-80 and the detection of fluorescence. Thus it was noted that $\mathrm{U} 251 \mathrm{~N}$, and not astrocytes, was the predominant source of plasminogen (Fig. 6A).

Western blots under nonreducing conditions were used for uPA analysis. In cell lysate preparations high levels of pro-uPA (high-molecular-weight uPA) were detected in astrocytes, but not in U251N cells (Fig. 6B). Conversely, in the conditioned media, U251N cultures contained high pro-uPA levels, whereas astrocytes had lower amounts (Fig. $6 C$ ). These results suggest the presence of a receptor for $\mathrm{UPA}$, likely $\mathrm{UPAR}$, on astrocytes; this receptor thus would anchor uPA to cells, accounting for higher levels of uPA in astrocyte cell lysates as compared with conditioned media. The converse would be the case for gliomas, in which a low uPAR expression would cause much of the uPA that was produced to be noncell-associated.

uPAR expression was determined by immunoblot and immunofluorescence techniques. Figure $6 \mathrm{D}$ demonstrates that uPAR levels were high in astrocytes and relatively low in glioma cells. This was confirmed by cellular localization whereby astrocytes, but not U251N, have detectable uPAR immunoreactivity (Fig. $7 A-D)$.

The requirement of live astrocytes for MMP-2 activation in cocultures was predicted earlier (Fig. 3). The analyses of the uPAplasmin cascade suggest that the uPAR receptor is a key reason for the necessity of live astrocytes. These observations predict that
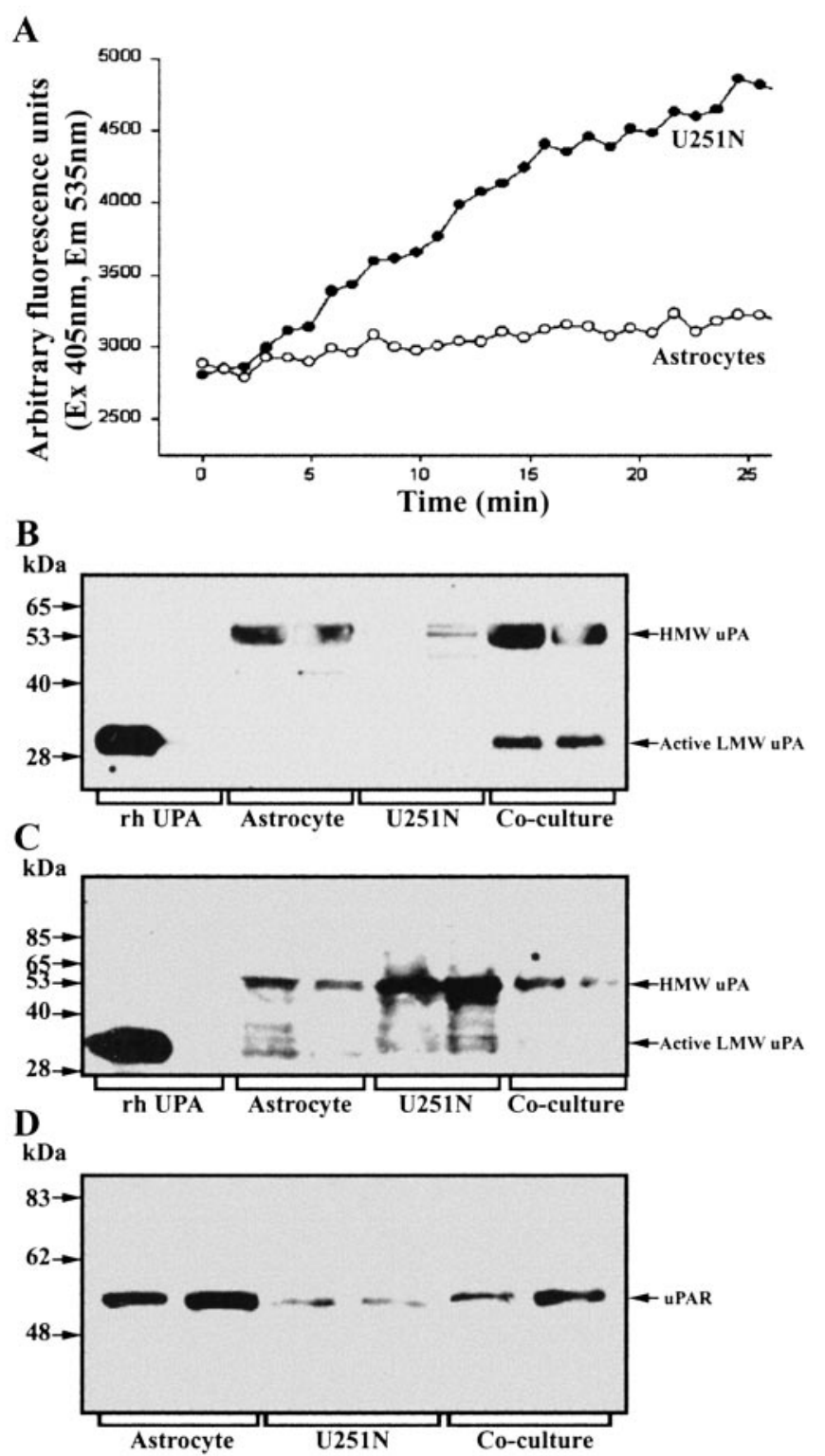

Figure 6. Contribution of components of the uPAR-plasmin cascade by astrocytes or glioma cells. A, Plasminogen content was determined by the use of the fluorochrome-conjugated plasmin substrate AFC-80; here, $10 \mu \mathrm{m}$ uPA was applied to conditioned media to convert plasminogen to plasmin, the activity of which was monitored. Note that the U251N glioma cells (open circles), rather than astrocytes (filled circles), were the principal sources of plasminogen. This result was replicated three times. $B, C$, Western blots of cell lysates or conditioned media, respectively, of uPA expression by astrocytes and U251N cells. The cell lysate analyses ( $B$ ) show high uPA levels for astrocytes, but not for U251N cells, whereas the converse is true for conditioned media ( $C$. D, Western blot for uPAR that documents higher expression in astrocytes rather than in glioma cells.

the removal of UPAR from the surface of astrocytes would prevent the activation of MMP-2 in glioma-astrocyte cocultures. Because UPAR is a glycosyl-phosphatidylinositol (GPI)anchored protein (Stahl and Mueller, 1995) and is susceptible to cleavage by phospholipase-C $\gamma$ (PI-PLC) (Pyke et al., 1993), we chose to manipulate UPAR levels on astrocytes by PI-PLC; we caution that the PI-PLC treatment will remove all GPI-linked proteins in addition to uPAR. We first determined the conditions necessary to maintain a prolonged depletion of uPAR from the surface of cells. When astrocytes were treated with PI-PLC (10 $\mathrm{U} / \mathrm{ml}$ ) for $1 \mathrm{hr}$, uPAR immunofluorescence was lost (Fig. 7E,F). 

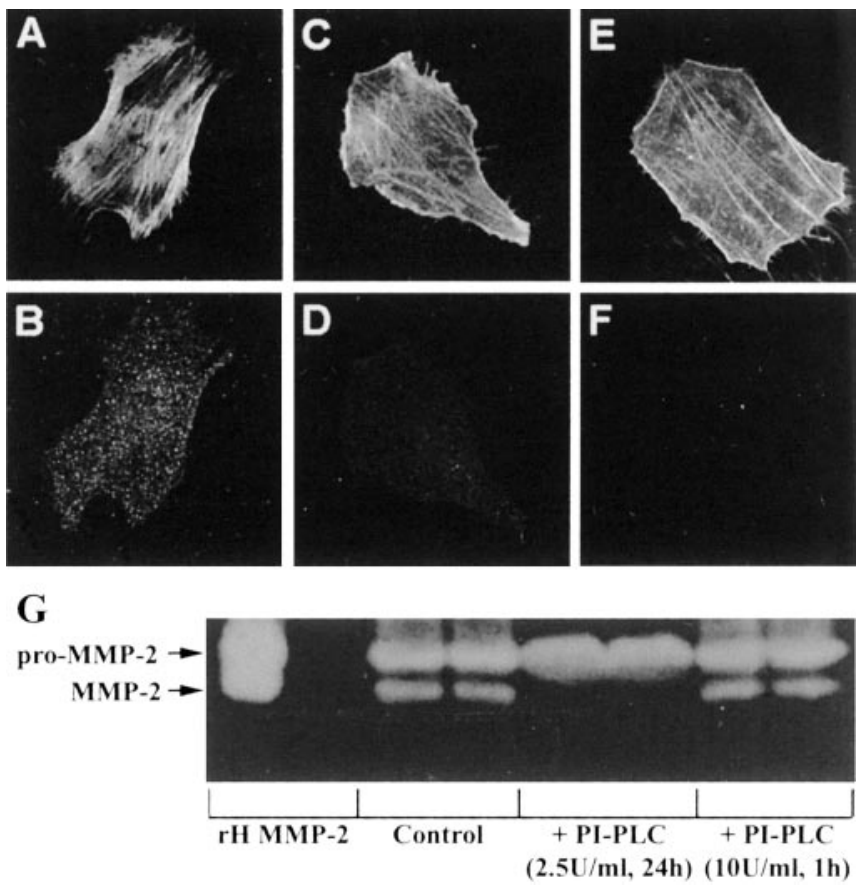

Figure 7. Detection of uPAR on astrocytes by immunofluorescence. Astrocytes have high expression of uPAR $(B)$, whereas U251N cells have very low levels $(D)$. Astrocytes $(A)$ and glioma cells ( $C$ ) were counterstained with phalloidin, which binds to filamentous actin, to delineate the boundary of each cell type. The specificity of the uPAR antibody was tested with an uPAR peptide (Santa Cruz Biotechnology, Santa Cruz, CA); when the uPAR antibody was preincubated with the uPAR peptide, subsequent staining of astrocytes with this antibody mixture was negative (data not shown). E, F, Astrocytes were treated with PI-PLC (2.5 U/ml) for $24 \mathrm{hr}$ and then immunostained for uPAR. After PI-PLC treatment the astrocytes ( $E$; phalloidin staining) were no longer immunoreactive for uPAR ( F). Finally, continuous $2.5 \mathrm{U} / \mathrm{ml} \mathrm{PI-PLC} \mathrm{for} 24 \mathrm{hr}$ (but not $10 \mathrm{U} / \mathrm{ml} \mathrm{PI-PLC}$ for $1 \mathrm{hr}$, followed by $23 \mathrm{hr}$ of recovery) abrogated the activation of MMP-2 in glioma-astrocyte interaction ( $G$ ).

However, when astrocytes were allowed to recover for $24 \mathrm{hr}$ after the $1 \mathrm{hr}$ of PI-PLC treatment, uPAR immunoreactivity reappeared. So that the prolonged absence of UPAR could be maintained, it was necessary to treat astrocytes continuously for $24 \mathrm{hr}$ with a lower amount $(2.5 \mathrm{U} / \mathrm{ml})$ of PI-PLC (Fig. $7 E, F)$. This treatment was not toxic to cells as determined by an MTT viability assay. Astrocytes with PI-PLC (2.5 U/ml, $24 \mathrm{hr})$ had similar levels of viability $(0.503 \pm 0.047$ MTT absorbance units $)$ compared with untreated astrocytes $(0.497 \pm 0.006)$. Furthermore, $\mathrm{U} 251 \mathrm{~N}$ cells treated with PI-PLC displayed viability levels $(0.607 \pm 0.027$ absorbance units $)$ corresponding to untreated cells ( $0.713 \pm 0.021$ absorbance units).

We addressed the consequence of astrocyte-U251N cocultures treated for $24 \mathrm{hr}$ with $2.5 \mathrm{U} / \mathrm{ml}$ of PI-PLC; no activation of MMP-2 occurred, thereby confirming a key role for the uPARplasmin cascade in the activation of MMP-2 (Fig. 7G).

Functional implications: targeting the uPA-plasmin cascade affects the transmigration of glioma cells across astrocytes The invasive capacity of U251N cells was examined by seeding them in invasion chambers coated with an artificial extracellular matrix (ECM) barrier, Matrigel. After 68 hr, $287 \pm 106 \mathrm{U} 251 \mathrm{~N}$ cells (the counting of five fields) were observed to have transmigrated through the barrier. When astrocytes were seeded along with U251N cells, significantly more U251N cells ( $663 \pm 40$ cells) transmigrated across Matrigel (Fig. 8A). Thus astrocytes facilitated the invasion of glioma cells.
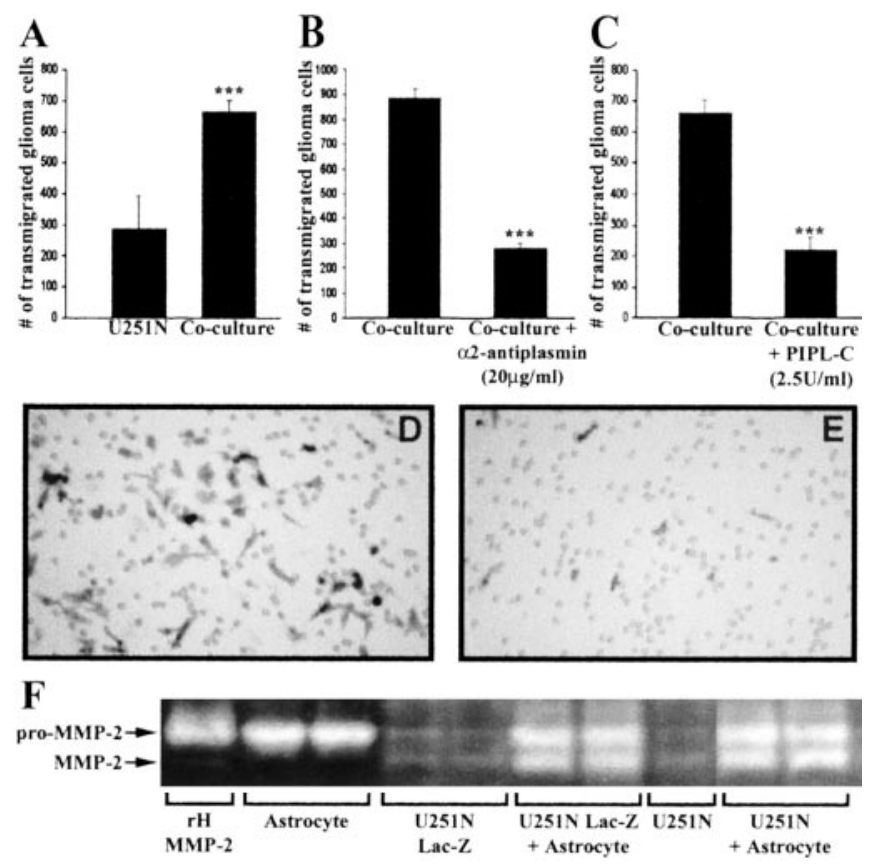

Figure 8. Inhibition of plasmin or the removal of uPAR by PI-PLC decreases transmigration of U251N cells in invasion assays. Lac-Z U251N cells (25,000 cells) cocultured with astrocytes (10,000 cells) resulted in a high number of glioma cells transmigrating through the Matrigelcoated Boyden invasion chambers by $68 \mathrm{hr}(A)$. The addition to the coculture of $\alpha 2$-antiplasmin $(B)$ or PI-PLC ( ; with PI-PLC replenished at 24 and $48 \mathrm{hr}$ ) significantly decreased the number of U251N cells invading through the chamber. This experiment was replicated three times. Values are the mean \pm SEM of triplicate samples; Student's $t$ test, ${ }^{* * *} p<0.001 . D, E$, Representative micrographs of U251N cells, identified after staining for $\beta$-galactosidase, that have invaded across Matrigel in a control coculture $(D)$ or in a coculture treated with inhibitors $(E)$. The holes in $D$ and $E$ are the $8 \mu \mathrm{m}$ pores present in the filter that supports the Matrigel barrier. $F$, Control experiment to indicate that the Lac- $Z$ transfectants (U251N Lac-Z) indeed are behaving in a similar manner to the parent line (U251N) with respect to the activation of MMP-2 in gliomaastrocytes cocultures.

It should be noted that the U251N cells used for invasion assays were transfected with Lac-Z to be able to distinguish them from astrocytes. Figure $8 F$ confirmed that the Lac- $Z$ transfectants behaved similarly to their parental line with respect to the activation of MMP-2 when cocultured with astrocytes.

The mechanisms that facilitated the increased transmigration of glioma cells across an astrocyte substratum were examined. The inhibition of plasmin by $\alpha_{2}$-antiplasmin $(20 \mu \mathrm{g} / \mathrm{ml})$ significantly reduced the number of $U 251 \mathrm{~N}$ cells that invaded (Fig. 8 B). Similarly, invasion assays conducted in the presence of PI-PLC ( $2.5 \mathrm{U} / \mathrm{ml}$; replenished at 24 and $48 \mathrm{hr}$ ) showed a lower number of invading U251N cells in comparison to U251N cells without PIPLC (Fig. 8C).

Collectively, these results demonstrate that astrocytes promote the invasive capacity of glioma cells via the activation of MMP-2. Inhibition of the generation of active MMP-2 in glioma-astrocyte cocultures reduces the transmigration of glioma cells that is facilitated by astrocytes.

\section{Plasminogen is expressed by glioma cells in situ}

We sought to determine whether the protease cascade described here has relevance in vivo. To this end we used a human glioblastoma specimen and immunohistochemistry to address whether particular proteins were expressed preferentially by glioma or astrocytes. However, all of the antibodies that we used (against MMP-2, uPA, or uPAR) did not work convincingly on any cellu- 


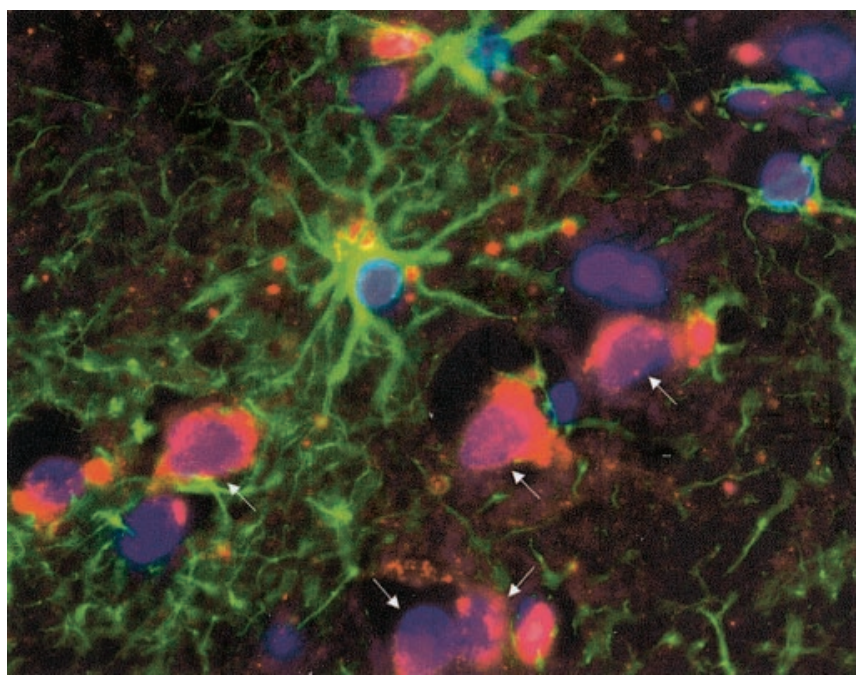

Figure 9. Plasminogen is expressed by glioma cells, but not by astrocytes, in vivo. A human glioblastoma brain section was immunolabeled for GFAP (green) to identify astrocytes that were in close proximity to tumor cells that were GFAP-negative; note that we selected specifically a glioblastoma sample that was GFAP-negative for glioma cells to allow for differentiation from astrocytes. Tumor cells were identified further by the size of their nuclei, which were larger than those of glia, and by the use of phase-contrast microscopy, whereby they could be distinguished from neurons with apical dendrites and a pyramidal morphology. Note that plasminogen (red) is expressed by the glioma cells (arrows). All nuclei were labeled by Hoechst dye (blue). We counted the proportions of glioma or astrocytes at the leading edge of tumor that were positive for plasminogen expression; three high-powered fields were sampled. Although no reactive astrocytes were scored positive, 19 of 23 (83\%) convincingly identified glioma cells expressed plasminogen. Original magnification, $1000 \times$.

lar structures in the deparaffinized tissue sections, with the exception of the antibody to plasminogen. Thus we found that the antibody to plasminogen labeled tumor cells in situ; in contrast, reactive astrocytes that were identified by GFAP immunoreactivity were negative for plasminogen expression (Fig. 9). These results provided support that the in vitro results presented here have relevance to tumor biology in vivo.

\section{Discussion}

The microenvironment of tumor cells is recognized to be pivotal to the growth of the tumor (Uhm et al., 1997; Liotta and Kohn, 2001). Within this milieu tumor cells interact with one another and with stromal cells via gap junctions, integrins, growth factors, and other mechanisms to enhance their survival and proliferative and invasive capacity. The possibility that malignant gliomas exploit their nontransformed surrounding has not been investigated previously. Such a study is relevant because the ability of glioma cells to invade diffusely throughout the CNS is a major factor that accounts for the high mortality and morbidity of the disease (Holland, 2000). The possibility of glioma-astrocyte interactions is supported by the observation that astrocytes become reactive around glioma cells in human and rodent specimens (Fig. 1). Furthermore, glioma cells have been found to produce factors that promote the proliferation (Couldwell et al., 1992) and motility (Lal et al., 1996) of astrocytes. More recently, astrocytes were found to contribute to the brain-metastatic capacity of melanoma cells via the production of an extracellular matrixdegrading protease, heparanase (Marchetti et al., 2000).

In this study we have addressed whether glioma cells could be manipulating astrocytes to increase their invasiveness. Specifically, we have evaluated the production and activation of MMP-2 in glioma-astrocyte interaction, because resected glioma speci- mens have high MMP-2 levels in comparison to normal brain tissue (Saxena et al., 1995; Forsyth et al., 1998; Lampert et al., 1998; Pagenstecher et al., 2001). Moreover, the expression of MMP-2 is correlated with the invasiveness of glioma cells in vitro (Apodaca et al., 1990; Rutka et al., 1995; Uhm et al., 1996; Forsyth et al., 1999; Nakada et al., 1999, 2001; Wild-Bode et al., 2001). Conversely, a fragment derived from the autocatalytic digestion of MMP-2, called PEX, acts simultaneously as an inhibitor of glioma angiogenesis, cell proliferation, and migration (Bello et al., 2001).

We have observed that astrocytes, rather than the U251N glioma line, are the predominant sources of pro-MMP-2 in vitro (Fig. 2). This mirrors the finding for several other tumor types, such as breast, colon, and lung cancers, in which stromal cells have been identified to be the principal producers of tumorassociated MMPs (Heppner et al., 1996; Yamamoto et al., 1996; Polette et al., 1997; Lim et al., 1998; Lochter and Bissell, 1999). In the coculture of glioma with astrocytes, activation of MMP-2 occurred although we found no evidence that total MMP-2 levels were altered. The mechanism of MMP-2 activation involves the uPA-plasmin cascade, because plasmin was generated in the cocultures, and the inhibition of plasmin (Fig. 4) or the removal of uPAR (Fig. 7) prevented the activation of MMP-2 in gliomaastrocyte cocultures. The uPA-plasmin cascade, with resultant MMP-2 activation, led to increased transmigration of glioma cells across a Matrigel barrier in the presence of astrocytes when compared with glioma cells cultured alone (Fig. 8). In correspondence with the biochemical results that $\alpha 2$-antiplasmin and PIPLC prevented MMP-2 activation, these treatments also prevented the transmigration of glioma cells facilitated by astrocytes.

The current results provide the novel hypothesis that an intricate interaction between astrocytes and glioma facilitates the invasive capacity of the latter via the uPA-plasmin cascade. In this regard, the activation of $\mathrm{UPA}$, by binding to $\mathrm{UPAR}$, converts the plasminogen zymogen to plasmin. The latter converts proMMP-2 to its activated form, leading to ECM degradation and allowing glioma cells to advance. In addressing the relative contribution by glioma cells or astrocytes of components of the UPAplasmin cascade, we found that uPAR (Figs. 6, 7) and proMMP-2 (Fig. 2) were expressed principally by astrocytes, uPA was supplied by both cell types, and plasminogen was the only glioma-specific component (Fig. 6). Indeed, the results indicate that plasminogen was the only factor that glioma cells need to produce, with astrocytes providing the other necessary components. In support to this in vitro cascade, we found that glioblastoma cells in situ, but not astrocytes, express plasminogen (Fig. 9). These results of glioma-astrocyte interaction support the concept that glioma cells exploit their environment to achieve increased invasiveness.

It is worthwhile noting that tumor cells use several other mechanisms that involve the solicitation of their neighbors. For example, A2058 melanoma cells express an abundance of proMMP-1 but lack the machinery to activate it. Fibroblasts produce a soluble factor that activates pro-MMP-1 of the A2058 cells, allowing the transmigration of A2058 cells through collagen barrier chambers (Benbow et al., 1999). Similarly, EMMPRIN (extracellular MMP inducer) is a $55 \mathrm{kDa}$ protein produced by tumor cells that induces the expression of several MMP members in stromal fibroblasts (Biswas et al., 1995); the expression of EMMPRIN in gliomas rises with increasing grades of malignancy (Sameshima et al., 2000). Conversely, stromal cells have the ability to induce MMP production in several different types of tumor 
cells (Martorana et al., 1998), demonstrating that the interactions between tumor and stromal cells are intricate and complex.

Although MMPs are discussed here with respect to invasiveness, it should be emphasized that MMPs also regulate other aspects of tumorigenicity, such as survival, proliferation, and angiogenesis (McCawley and Matrisian, 2000; Yu and Stamenkovic, 2000). It remains to be determined whether glioma-astrocyte interactions affect other aspects of glioma behavior via MMPs.

Future studies will address whether the mechanisms of MMP-2 activation described here are generalizable across a majority of glioma cell lines; the phenomenon was observed to be identical when another two lines, LN308 and LN18, were used (data not shown). However, we also have noted that some glioma lines express both the pro- and active forms of MMP-2, so it is likely that these are endowed with the machinery to produce and activate their own MMP-2. It would be interesting to test whether these glioma lines express high uPAR levels and other members of the uPA-plasmin cascade, thus negating the need to involve their astrocyte environment for MMP-2 activation.

Conceptually, it is not clear whether lines that express multiple components of the uPA-plasmin cascade and that have the ability to autoactivate their own MMP-2 are more or less transformed/malignant than glioma lines that use other cells to activate MMP-2. It is rational to surmise that, as tumors evolve, they acquire the necessary machinery to become more self-sufficient and, therefore, their dependency on the stromal environment is diminished. In this regard the $\mathrm{U} 251 \mathrm{~N}$ cell line could be representative of a less evolved glioma that remains dependent on its stromal milieu to invade. On the other hand, because glioma cells are reported to focus their efforts at either proliferating or migrating (the "go or grow" phenomenon; Berens and Giese, 1999), one may argue that the $\mathrm{U} 251 \mathrm{~N}$ line is more evolved than lines that cannot exploit their milieu, because more energy then could be focused on growth. Regardless, the current results provide evidence, for the first time, that glioma cells have the potential to recruit astrocytes to activate MMP-2 for increased invasiveness. We also invite the testable hypothesis that the preferential spread of glioma cells along white matter tracts in vivo (Holland, 2000) is the result of a subpopulation of uPAR-enriched astrocytes in these locations.

The involvement of uPAR in initiating the cascade that leads to the activation of MMP-2 helps to explain the previous observation that inhibition of uPAR expression on glioma cells decreases their invasiveness (Go et al., 1997; Mohanam et al., 2001). Although uPAR has several activities, including modulating the activity of integrins, the current findings provide an alternate mechanism for the correlation of UPAR expression with increased invasiveness of glioma cells.

Patients with high-grade gliomas continue to have a very poor outcome, one in which only $10 \%$ will survive beyond 2 years. A major cause of the high mortality is the inability to excise all tumor cells surgically, leading to the regrowth and dissemination of cells to form several distinct tumor masses within the CNS. Thus new therapies that suppress glioma invasiveness should improve the prognosis of patients with malignant gliomas. The current results suggest that disruption of the uPA-plasmin cascade, resulting in the inhibition of MMP-2 activity, may improve the treatment of gliomas. Targeting the uPA-plasmin system could involve the inhibition of binding of uPA to UPAR (Min et al., 1996) or interfering with the direct activity of plasmin and uPA (Goodson et al., 1994). Alternatively, inhibiting or downregulating the expression of UPAR, the initiator of the plasmin-MMP-2 pathway in glioma-astrocyte interactions, may be beneficial. For example, SNB19 glioma cells transfected to express antisense uPAR were no longer able to invade into rat brain aggregates (Go et al., 1997). Finally, targeting MMP-2 activity directly, via the judicious use of inhibitors of MMPs, also may prove to be beneficial.

In summary, the current results demonstrate that the close proximity of glioma cells and astrocytes in situ results in exploitation of the astrocyte environment by glioma cells, leading to a remodeling of the surrounding matrix and increased invasiveness of malignant glioma cells.

\section{References}

Andreasen PA, Egelund R, Petersen HH (2000) The plasminogen activation system in tumor growth, invasion, and metastasis. Cell Mol Life Sci 57:25-40.

Apodaca G, Rutka JT, Bouhana K, Berens ME, Giblin JR, Rosenblum ML, McKerrow JH, Banda MJ (1990) Expression of metalloproteinases and metalloproteinase inhibitors by fetal astrocytes and glioma cells. Cancer Res 50:2322-2329.

Beliveau R, Delbecchi L, Beaulieu E, Mousseau N, Kachra Z, Berthelet F, Moumdjian R, Del Maestro R (1999) Expression of matrix metalloproteinases and their inhibitors in human brain tumors. Ann NY Acad Sci 886:236-239.

Bello L, Lucini V, Carrabba G, Giussani C, Machluf M, Pluderi M, Nikas D, Zhang J, Tomei G, Villani RM, Carroll RS, Bikfalvi A, Black PM (2001) Simultaneous inhibition of glioma angiogenesis, cell proliferation, and invasion by a naturally occurring fragment of human metalloproteinase-2. Cancer Res 61:8730-8736.

Benbow U, Schoenermark MP, Mitchell TI, Rutter JL, Shimokawa K, Nagase H, Brinckerhoff CE (1999) A novel host/tumor cell interaction activates matrix metalloproteinase-1 and mediates invasion through type I collagen. J Biol Chem 274:25371-25378.

Berens ME, Giese A (1999) Those left behind. Biology and oncology of invasive glioma cells. Neoplasia 1:208-219.

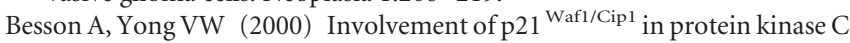
$\alpha$-induced cell cycle progression. Mol Cell Biol 20:4580-4590.

Biswas C, Zhang Y, DeCastro R, Guo H, Nakamura T, Kataoka H, Nabeshma K (1995) The human tumor cell-derived collagenase stimulatory factor (renamed EMMPRIN) is a member of the immunoglobulin superfamily. Cancer Res 55:434-439.

Boutros T, Croze E, Yong VW (1997) Interferon- $\beta$ is a potent promoter of nerve growth factor production by astrocytes. J Neurochem 69:939-946.

Chambers AF, Matrisian LM (1997) Changing views of the role of matrix metalloproteinases in metastasis. J Natl Cancer Inst 89:1260-1270.

Couldwell WT, Yong VW, Dore-Duffy P, Freedman MS, Antel JP (1992) Production of soluble autocrine inhibitory factors by human glioma cell lines. J Neurol Sci 110:178-185.

Forsyth PA, Laing TD, Gibson AW, Rewcastle NB, Brasher P, Sutherland G, Johnston RN, Edwards DR (1998) High levels of gelatinase-B and active gelatinase-A in metastatic glioblastoma. J Neurooncol 36:21-29.

Forsyth PA, Wong H, Laing TD, Rewcastle NB, Morris DG, Muzik H, Leco KJ, Johnston RN, Brasher PM, Sutherland G, Edwards DR (1999) Gelatinase-A (MMP-2), gelatinase-B (MMP-9), and membrane-type matrix metalloproteinase-1 (MT1-MMP) are involved in different aspects of the pathophysiology of malignant gliomas. Br J Cancer 79:1828-1835.

Forsyth PA, Lafleur M, Edwards D, Yong VW (2001) Proteases and their inhibitors in gliomas. In: Role of proteases in the pathophysiology of neurodegenerative diseases (Lajtha A, Banik NL, eds), pp 241-268. New York: Kluwer Academic.

Go Y, Chintala SK, Mohanam S, Gokaslan Z, Venkaiah B, Bjerkvig R, Oka K, Nicolson GL, Sawaya R, Rao JS (1997) Inhibition of in vivo tumorigenicity and invasiveness of a human glioblastoma cell line transfected with antisense uPAR vectors. Clin Exp Metastasis 15:440-446.

Goodson RJ, Doyle MV, Kaufman SE, Rosenberg S (1994) High-affinity urokinase receptor antagonists identified with bacteriophage peptide display. Proc Natl Acad Sci USA 91:7129-7133.

Heppner KJ, Matrisian LM, Jensen RA, Rodgers WH (1996) Expression of most matrix metalloproteinase family members in breast cancer represents a tumor-induced host response. Am J Pathol 149:273-282.

Holland EC (2000) Glioblastoma multiforme: the terminator. Proc Natl Acad Sci USA 97:6242-6244. 
Ishii N, Maier D, Merlo A, Tada M, Sawamura Y, Diserens AC, Van Meir EG (1999) Frequent coalterations of TP53, p16/CDKN2A, p14ARF, PTEN tumor suppressor genes in human glioma cell lines. Brain Pathol 9:469-479.

Lal PG, Ghirnikar RS, Eng LF (1996) Astrocyte-astrocytoma cell line interactions in culture. J Neurosci Res 44:216-222.

Lampert K, Machein U, Machein MR, Conca W, Peter HH, Volk B (1998) Expression of matrix metalloproteinases and their tissue inhibitors in human brain tumors. Am J Pathol 153:429-437.

Lim M, Martinez T, Jablons D, Cameron R, Guo H, Toole BP, Li JD, Basbaum C (1998) Tumor-derived EMMPRIN stimulates collagenase transcription through MAPK. FEBS Lett 441:88-92.

Liotta LA, Kohn EC (2001) The microenvironment of the tumour-host interface. Nature 411:375-379.

Lochter A, Bissell MJ (1999) An odyssey from breast to bone: multi-step control of mammary metastases and osteolysis by matrix metalloproteinases. APMIS 107:128-136.

Marchetti D, Li J, Shen R (2000) Astrocytes contribute to the brainmetastatic specificity of melanoma cells by producing heparanase. Cancer Res 60:4764-4770.

Martorana AM, Zheng G, Crowe TC, O’Grady RL, Lyons JG (1998) Epithelial cells up-regulate matrix metalloproteinases in cells within the same mammary carcinoma that have undergone an epithelial-mesenchymal transition. Cancer Res 58:4970-4979.

Mazzieri R, Masiero L, Zanetta L, Monea S, Onisto M, Garbisa S, Mignatti P (1997) Control of type IV collagenase activity by components of the urokinase-plasmin system: a regulatory mechanism with cell-bound reactants. EMBO J 16:2319-2332.

McCawley LJ, Matrisian LM (2000) Matrix metalloproteinases: multifunctional contributors to tumor progression. Mol Med Today 6:149-158.

Min HY, Doyle LV, Vitt CR, Zandonella CL, Stratton-Thomas JR, Shuman MA, Rosenberg S (1996) Urokinase receptor antagonists inhibit angiogenesis and primary tumor growth in syngeneic mice. Cancer Res 56:2428-2433.

Mohanam S, Jasti SL, Kondraganti SR, Chandrasekar N, Kin Y, Fuller GN, Rao JS (2001) Stable transfection of urokinase-type plasminogen activator antisense construct modulates invasion of human glioblastoma cells. Clin Cancer Res 7:2519-2526.

Nagase H (1997) Activation mechanisms of matrix metalloproteinases. Biol Chem 378:151-160.

Nakada M, Nakamra H, Ikeda E, Fujimoto N, Yamashita J, Sato M, Seiki Y (1999) Expression and tissue localization of membrane-type 1, 2, and 3 matrix metalloproteinases in human astrocytic tumors. Am J Pathol 154:417-428.

Nakada M, Kita D, Futami K, Yamashita J, Fujimoto N, Sato H, Okada Y (2001) Roles of membrane-type 1 matrix metalloproteinase and tissue inhibitor of metalloproteinases- 2 in invasion and dissemination of human malignant glioma. J Neurosurg 94:464-473.

Pagenstecher A, Wussler EM, Opdenakker G, Volk B, Campbell IL (2001) Distinct expression patterns and levels of enzymatic activity of matrix metalloproteinases and their inhibitors in primary brain tumors. J Neuropathol Exp Neurol 60:598-612.

Pei D, Weiss S (1996) Transmembrane-deletion mutants of the membranetype matrix metalloproteinase-1 process pro-gelatinase A and express intrinsic matrix-degrading activity. J Biol Chem 271:9135-9140.

Polette M, Gilles C, Marchand V, Lorenzato M, Toole B, Tournier JM, Zucker S, Birembaut P (1997) Tumor collagenase stimulatory factor (TCSF) expression and localization in human lung and breast cancers. J Histochem Cytochem 45:703-709.

Price A, Shi Q, Morris D, Wilcox ME, Brasher PMA, Rewcastle NB, Shalinsky D, Appelt K, Johnston RN, Yong VW, Edwards D, Forsyth P (1999) Marked inhibition of tumor growth in a malignant glioma tumor model by a novel synthetic matrix metalloproteinase inhibitor AG3340. Clin Cancer Res 5:845-854.
Pyke C, Eriksen J, Solberg H, Nielsen BS, Kristensen P, Lund LR, Dano K (1993) An alternatively spliced variant of mRNA for the human receptor for urokinase plasminogen activator. FEBS Lett 326:69-74.

Rutka JT, Smith SL (1993) Transfection of human astrocytoma cells with glial fibrillary acidic protein complementary DNA: analysis of expression, proliferation, and tumorigenicity. Cancer Res 53:3624-3631.

Rutka JT, Matsuzawa K, Hubbard SL, Fukuyama K, Becker LE, StetlerStevenson W, Edwards DR, Dirks PB (1995) Expression of TIMP-1, TIMP-2, 72- and 92-kDa type IV collagenase transcripts in human astrocytoma cell lines: correlation with astrocytoma cell invasiveness. Int J Oncol 6:877-884.

Sameshima T, Nabeshima K, Toole BP, Yokogami K, Okada Y, Goya T, Koono M, Wakisaka S (2000) Expression of EMMPRIN (CD147), a cell surface inducer of matrix metalloproteinases, in normal human brain and gliomas. Int J Cancer 88:21-27.

Sawaya RE, Yamamoto M, Gokaslan ZL, Wang SW, Mohanam S, Fuller GN, McCutcheon, Stetler-Stevenson WG, Nicolson GL, Rao JS (1996) Expression and localization of $72 \mathrm{kDa}$ type IV collagenase (MMP-2) in human malignant gliomas in vivo. Clin Exp Metastasis 14:35-42.

Saxena A, Robertson JT, Kufta C (1995) Increased expression of gelatinase A and TIMP-2 in primary human glioblastomas. Int J Oncol 7:469-473.

Stahl A, Mueller BM (1995) The urokinase-type plasminogen activator receptor, a GPI-linked protein, is localized in caveolae. J Cell Biol 129:335-344.

Sternlicht MD, Werb Z (2001) How matrix metalloproteinases regulate cell behavior. Annu Rev Cell Dev Biol 17:463-516.

Stetler-Stevenson WG, Aznavoorian S, Liotta LA (1993) Tumor cell interactions with the extracellular matrix during invasion and metastasis. Annu Rev Cell Biol 9:541-573.

Tonn JC, Kerkau S, Hanke A, Bouterfa H, Mueller JG, Wagner S, Vince GH, Roosen K (1999) Effect of synthetic matrix-metalloproteinase inhibitors on invasive capacity and proliferation of human malignant gliomas in vitro. Int J Cancer 80:764-772.

Uhm JH, Dooley NP, Villemure JG, Yong VW (1996) Glioma invasion in vitro: regulation by matrix metalloprotease- 2 and protein kinase C. Clin Exp Metastasis 14:421-433.

Uhm JH, Dooley NP, Villemure JG, Yong VW (1997) Mechanisms of glioma invasion: role of matrix metalloproteinases. Can J Neurol Sci 24:3-15.

VanMeter TE, Rooprai HK, Kibble MM, Fillmore HL, Broaddus WC, Pilkington GJ (2001) The role of matrix metalloproteinase genes in glioma invasion: co-dependent and interactive proteolysis. J Neurooncol 53:213-235.

Vecil GG, Larsen PH, Herx LM, Besson A, Goodyer CG, Yong VW (2000) Interleukin-1 is a key regulator of matrix metalloproteinase- 9 in human neurons in culture and following mouse brain trauma in vivo. J Neurosci Res 61:212-224.

Wild-Bode C, Weller M, Wick W (2001) Molecular determinants of glioma cell migration and invasion. J Neurosurg 94:978-984.

Yamamoto M, Mohanam S, Sawaya R, Fuller GN, Seiki M, Sato H, Gokaslan ZL, Liotta LA, Nicolson GL, Rao JS (1996) Differential expression of membrane-type matrix metalloproteinase and its correlation with gelatinase A activation in human malignant brain tumors in vivo and in vitro. Cancer Res 56:384-392.

Yong VW (1998) Response of astrocytes and oligodendrocytes to injury. Ment Retard Dev Disabil Res Rev 4:193-199.

Yong VW, Power C, Forsyth P, Edwards DR (2001) Metalloproteinases in biology and pathology of the nervous system. Nat Rev Neurosci 2:502-511.

Yu Q, Stamenkovic I (2000) Cell surface-localized matrix metalloproteinase-9 proteolytically activates TGF- $\beta$ and promotes tumor invasion and angiogenesis. Genes Dev 14:163-176. 